\title{
THE MOVEMENT OF MELTING IGE OVER ROUGH SURFACES
}

\author{
By B. D. Chadbourne, * R. M. Cole, * S. Tootill* and M. E. R. Walford
}

(H. H. Wills Physics Laboratory, University of Bristol, Tyndall Avenue, Bristol BS8 ITL, England)

\begin{abstract}
Laboratory experiments show that pieces of melting ice about one centimetre across, moving under normal loads across roughened glass surfaces, travel much faster than regelation theory predicts. The discrepancy is as much as 40 times for the finest scale surfaces, (prepared by grinding with carborundum particles of $60 \mu \mathrm{m}$ mean diameter) and increases further if the load is reduced below three bars. On the other hand melting ice moves, under similar conditions, across rough porous glass surfaces at approximately the speed predicted by regelation theory. We suggest the reason is that melt water, produced by the dissipation of frictional energy, accumulates at the interface between ice and ground glass where it promotes sliding, but can easily drain away from a porous surface. Similar effects at the bed of a temperate glacier may cause the contribution of regelation to the bed-slip process to depend sensitively upon the melt-water regime.

RÉsumÉ. Le mouvemement de la glace fondante sur une surface rugueuse. Des expériences de laboratoire montrent que des morceaux de glace fondante d'environ un centimètre de diamètre, se déplaçant sous des pressions normales sur des surfaces de verre dépoli, avancent beaucoup plus vite que ne le prévoit la théorie du regel. La discordance va jusqu'à 40 fois pour les surfaces à aspérités les plus fines (préparées en broyant le verre avec des particules de carborundum de $60 \mu \mathrm{m}$ de diamètre moyen) et croît ensuite si la charge est réduite endessous de trois bars. Au contraire, la glace fondante, dans des conditions analogues, sur une surface en verre rugueuse et poreuse, se déplace approximativement à la vitesse prévue par la théorie du regel. Nous suggérons une explication selon laquelle l'eau de fusion, produite par la dissipation de l'énergie de frottement, s'accumule à l'interface entre la glace et le verre dépoli où elle accélère le glissement, tandis qu'elle peut facilement être évacuée à travers une surface poreuse. Des effets analogues sur le lit d'un glacier tempéré peuvent expliquer que la contribution du phénomène de regel au processus de glissement sur le lit dépende étroitement du régime de l'eau de fusion.
\end{abstract}

Zusammenfassung. Die Bewegung schmelzenden Eises uber rauhe Oberflächen. Laborversuche haben gezeigt, dass Stücke von schmelzendem Eis mit einem Durchmesser von etwa $1 \mathrm{~cm}$, die unter normaler Belastung über eine aufgerauhte Glasoberfläche gleiten, sich viel schneller bewegen als nach der Regelationstheorie zu erwarten wäre. Die Abweichung erreicht den Faktor 40 für Oberflächen mit feinster Struktur (hergestellt durch Schleifen mit Carborundum-Teilchen von $60 \mu \mathrm{m}$ mittlerem Durchmesser) und steigt noch weiter an, wenn die Belastung unter 3 bar fällt. Andrerseits gleitet schmelzendes Eis unter ähnlichen Bedingungen über rauhe, poröse Glasoberflächen ungefähr mit der von der Regelationstheorie vorhergesagten Geschwindigkeit. Nach unserer Meinung ist dies darauf zurückzuführen, dass Schmelzwasser, das sich durch die Ausbreitung der Reibungsenergie bildet, sich im Bereich zwischen Eis und Glasfläche sammelt, wo es Gleiten verursacht, während es von einer porösen Oberfläche leicht abfliessen kann. Ähnliche Wirkungen am Untergrund eines temperierten Gletschers können zur Folge haben, dass der Beitrag der Regelation zur Gletscherbewegung stark vom Schmelzwassersystem abhängt.

\section{INTRODUCTION}

Regelation is a well-known process by means of which small solid objects may pass through a piece of ice held at the melting point. Under the action of a driving force, melting occurs in regions of high pressure ahead of the body and the melt water flows away to refreeze behind the body where the pressure is low. The heat produced there is conducted back, through both ice and specimen, to the cooler, high-pressure regions. The essential physics of this process has been analysed independently by Ornstein (r9o6), Nye (1967), and Shreve (personal communication, also referred to by Drake and Shreve, 1973).

Quantitative agreement between theory and experiment is poor: the velocity of a regelating body is not proportional to the driving stress and may be as much as a thousand times smaller than expected. Drake and Shreve (1973) suggest why this is so. At low driving stresses, there is a heavy accumulation of impurities in solution behind the object, and this

* The experiments and analysis of the movement of ice over ground glass surfaces, together with a first draft of this paper, were the work of the first three co-authors, carried out as part of an undergraduate project in physics at the University of Bristol in 1973 . 
slows down the regelation process by reducing the temperature difference across the specimen. At higher stresses, the pressure behind the body falls to the triple-point pressure of water but cannot fall below this. It follows that any further increase of driving stress can only increase the mean pressure, and hence reduce the mean temperature around the specimen. Heat then flows from the surrounding ice into the body and produces a wake of melt water which carries away the accumulated impurities. The wake forms a tabular layer behind an insulating wire, but behind a conducting wire an irregular layer of water droplets is found because, in this case, the ice-water interface is unstable (Frank, 1967). The ice-water interface behind a conducting body must be significantly supercooled if the ice is to grow, as required, at the regelation velocity. This reduces the regelation velocity of a conducting wire by a factor of about ten. Drake and Shreve conclude that if all these effects are taken into account, a satisfactory, if approximate, quantitative theory of regelation results.

Quite apart from what we may conveniently call the Drake and Shreve effects, Nye (1973[a]) and Morris (unpublished) point out a difficulty which arises in applying the basic theory. If the thickness of the water film is calculated numerically for objects of complicated shape, regions of negative film thickness are found! Nye (1973[a]) shows that, to resolve this difficulty in the case of wires, one must take full account of the temperature difference across the thin water film surrounding the specimen. Even though this temperature difference is very small it can be significant because it allows the temperature gradient along the ice-water interface to differ, locally, from the gradient in the surface of the specimen. By this means Nye avoids negative film thicknesses occurring in the theory.

Regelation is important in nature because it contributes to glacier sliding. Weertman (1957) first suggested that ice near the bed of a temperate glacier deforms plastically around large obstacles and moves by regelation past smaller asperities. Weertman (1964) and Lliboutry (1968) carried out further investigation into this glaciological problem. Kamb (1970) and Nye (1969, 1970) independently give essentially exact analyses of a simplified problem. They treat a glacier as a Newtonian viscous material with the melting properties of pure ice, moving by deformation and regelation over a bed consisting of small slopes. This treatment provides an insight into the essential physics of the bed-slip process. In particular it applies when the bed is rough only on scales smaller than a centimetre: then the ice moves by pure regelation. The present paper reports laboratory experiments designed to test the theory in this regime, where surface roughnesses are much finer than the scale defined by Nye's critical wave number $k_{*}$ (Nye, r969).

\section{LABORATORY EXPERIMENTS}

We describe experiments in which melting ice is pulled, under a normal load, over a roughened glass surface. Suitable surfaces were prepared by grinding soda-glass plates with carborundum pastes. A paste designated as " 90 mesh" contains particles as large as $230 \mu \mathrm{m}$ across although the average dimension is $15^{0} \mu \mathrm{m}$. A low-power scanning electron micrograph (Fig. I) of the resulting ground surface reveals that coarse asperities are of order $50 \mu \mathrm{m}$ across and ro $\mu \mathrm{m}$ high. The surface appears to consist of small slopes and sharp edges, although higher magnification reveals a ragged structure with deep cracks and cavities up to a micrometre across. The large-scale asperities probably dominate the regelation process; the effect upon regelation of the small cracks and cavities is unknown.

Cylindrical ice samples $3.5 \mathrm{~cm}$ in diameter and length were prepared from distilled water. These samples had columnar grains a few millimetres across, and contained no visible bubbles. A sample was placed, cold, on a cold, inclined, roughened glass plate and loaded with weights by a sample holder and stirrup. The apparatus was left in a darkened refrigerator, at $0^{\circ} \mathrm{C}$ and after a few minutes the ice started to move down the plane. Its velocity was measured by time-lapse photographs of a small lamp attached to the sample holder. Reproducible results 

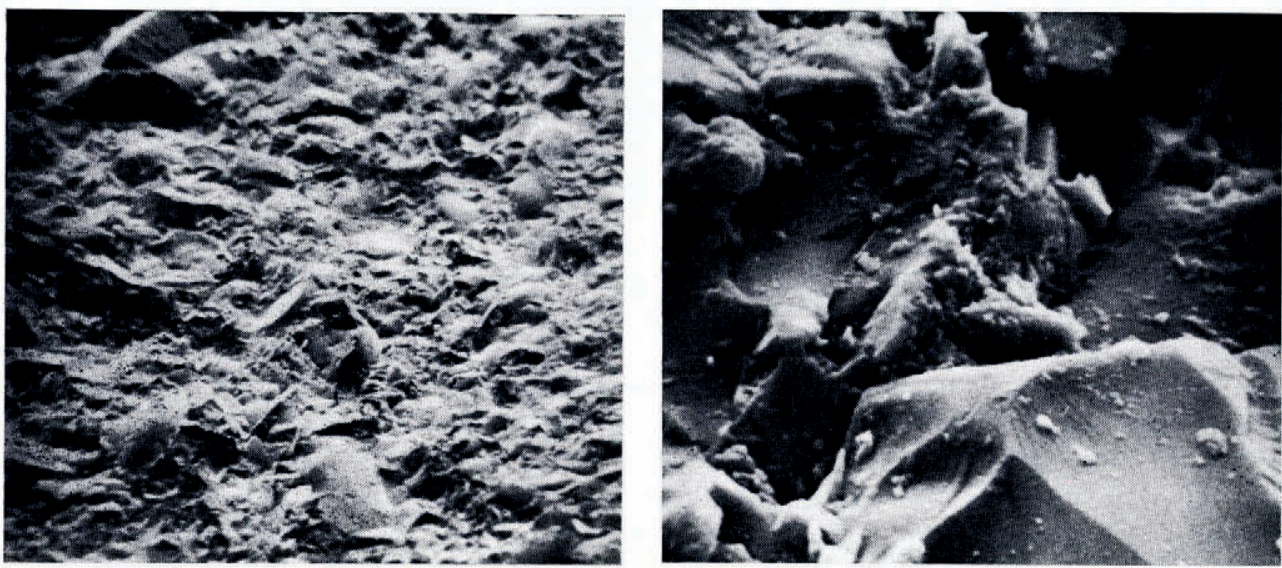

Fig. I. Scanning electron micrographs of the surface of soda glass after grinding with "go mesh" carborundum paste.

were obtained with this apparatus: the established ice velocity remained constant to within $10 \%$ and seemed independent of variation of order 1 deg in the ambient temperature of the refrigerator. After the experiment, the imprint of the roughened glass surface was clearly visible over a well-defined area of the ice sample.

We found that, under constant shear traction, the ice velocity at first decreased rapidly with increasing normal load but, when the load reached two or three bars, this effect was less marked. Subsequent experiments were therefore carried out with a normal load of three bars. They showed that the ice velocity varied linearly with shear traction for a given surface and was generally lower for rougher surfaces (Table I, section A). The results are qualitatively in agreement with the theory of Nye (1969). An approximate, quantitative comparison was

Table I. Measured sliding velocities compared with those calculated FROM REGELATION THEORY

The measured velocity at which ice moves, under a load, down various inclined, rough surfaces is compared with the velocity expected on the basis of regelation theory. Each ground glass surface in section A is identified by the mean diameter $d$ of the carborundum particles used to prepare the surface. In section $\mathrm{B}, p$ is the mean pore diameter quoted by the manufacturers of the sintered glass samples.

\section{Specimen}

A

$$
\begin{gathered}
\text { Coarse ground glass } \\
d=150 \mu \mathrm{m} \\
\text { Medium ground glass } \\
d=100 \mu \mathrm{m} \\
\text { Fine ground glass } \\
d=60 \mu \mathrm{m}
\end{gathered}
$$

B Coarse sintered glass $p=200 \mu \mathrm{m}$

Sintered glass $p=100 \mu \mathrm{m}$

Sintered glass $p=50 \mu \mathrm{m}$

Sintered glass $p=25 \mu \mathrm{m}$

Fine sintered glass $p=10 \mu \mathrm{m}$

\section{Measured velocity per unit tractive stress $\mu \mathrm{m} / \mathrm{s}$ bar}

$\begin{array}{lr}230 \pm 25 & 13 \pm 4 \\ 290 \pm 30 & 15 \pm 5 \\ 750 \pm 80 & 19 \pm 6 \\ 0.3 \pm 0.1 & 0.2 \pm 0.1 \\ 0.2 \pm 0.1 & 0.4 \pm 0.2 \\ 0.6 \pm 0.2 & 0.8 \pm 0.4 \\ 2.0 \pm 1.0 & 2.0 \pm 1.0 \\ 1.0 \pm 1.0 & 4.0 \pm 2.0\end{array}$

Expected velocity per unit tractive stress $\mu \mathrm{m} / \mathrm{s}$ bar

$4.0 \pm 2.0$ 
made using the expression $v=\alpha \tau \lambda / A^{2}$ for the velocity $v$ of ice moving under shear traction $\tau$ over a "washboard" surface with sinusoidal corrugations of wavelength $\lambda$ and amplitude $A$. $\alpha$ is a constant of value $25 \mu \mathrm{m}^{2} \mathrm{~s}^{-1} \mathrm{bar}^{-1}$. We judge, for example, that a washboard surface with $\lambda=20 \mu \mathrm{m}$ and $A=5 \mu \mathrm{m}$ has roughness of the same order as the surface shown in Figure $\mathrm{I}$. The velocity of regelation across this model surface was calculated to be $20 \mu \mathrm{m} \mathrm{s}^{-1}$. This is an order of magnitude less than $250 \mu \mathrm{m} \mathrm{s}^{-1}$, the measured ice velocity across the corresponding glass surface.

A more precise comparison between theory and experiment is based upon the analysis of a bed which is rough in both directions (Nye, r969). The horizontal scale of roughness is now described by the power spectral density of the surface instead of a single wavelength and amplitude. The statistical properties of the ground glass slides are measured by an optical diffraction technique, suggested by Professor J. F. Nye. A collimated monochromatic beam of light is directed normally onto the interface between the roughened glass and a transparent liquid. If glass and liquid have equal refractive indices, the light is transmitted without scattering. Conversely if the difference in refractive index is large, the transmitted light is diffusely scattered in accordance with Lambert's law. Dr M. V. Berry (personal communication) has shown that in the intermediate case the angular distribution of transmitted light is described by two additive terms which correspond to the unscattered and the diffusely scattered extreme cases. He showed how the power spectral density can be obtained from measurements of the scattering. Theoretical regelation velocities presented in Table I are based upon this analysis of roughness; these calculated velocities are accurate to $30 \%$ whilst the velocity measurements are accurate to $10 \%$. The previous approximate result is clearly confirmed; regelation velocities over the finest surfaces are as much as forty times greater than expected. We must now consider possible reasons for this discrepancy.

\section{Discussion}

Drake and Shreve (1973) found that the regelation of wires was controlled by the effects of supercooling, the triple point behaviour of water, and impurities. In the present experiments, supercooling is probably unimportant because glass is a poor thermal conductor. The triple point is unlikely to be reached: observations of the interface under the optical microscope confirm that vapour is visible there only when the normal force between ice and glass is greatly reduced. Impurities may be important: those initially present at the interface and in the layer of refrozen ice, may tend to accumulate at the interface, where refreezing occurs. However all the Drake and Shreve effects tend to reduce the observed regelation velocity below the theoretical value, whereas in the present experiments it is important to note that we observe an increase in velocity beyond the theoretical value. We conclude that the Drake and Shreve effects are not of controlling importance in our experiments. Instead we suggest that the high experimental velocities and the decrease in velocity as the normal load increases up to 2 or 3 bars, occur because more water is present at the ice-glass interface than is required by regelation theory.

We have no entirely adequate theory to deal with regelation in the presence of excess water; indeed the theory of regelation over rough surfaces, even without excess water, is not yet in a satisfactory state. Nye (1973[a]) and Morris (unpublished) point out that, as it stands, the theory predicts that a water film of negative thickness can occur in some regions of some beds! This difficulty is still unresolved, although a solution may be possible, following Nye (1973[a]), in which we take full account of temperature differences in the water film.

In the meantime, we assume that over a fraction $f$ of the contact area $A_{0}$ between ice and glass, regelation proceeds according to the Nye theory. The remaining area $(\mathrm{I}-f) A_{0}$ contains excess water and does not significantly contribute to the drag. This film of excess water may be melt water produced by the tractive work done, and we estimate its thickness $t$ 
as follows. Consider melt water generated uniformly, and at a constant rate, between two flat, parallel discs of area $(\mathrm{I}-f) A_{0}$ and separation $t$. Pressure builds up within the film until the rate of viscous extrusion of water around the edges of the discs equals the rate at which melt water is produced by thermal dissipation of tractive work. The pressure in the film is then just sufficient to support the load keeping the discs at separation $t$. We use values of the melt rate and load appropriate to the present experiments and we estimate $f$ by comparison with regelation theory. We then find, from this model, that $t$, the thickness of the excess water film, lies between o. I and I.o $\mu \mathrm{m}$. We think, therefore, sufficient melt water is produced by friction to account for our experimental observations: it produces a film of thickness less than the asperities of the ground glass surfaces but comparable with the water film required for regelation and too thin to be easily detected by optical means.

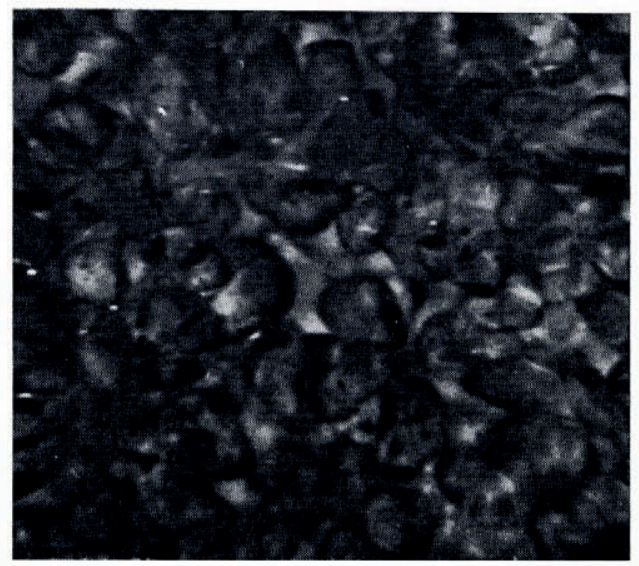

Fig. 2. Transmitted light photograph of sintered glass sample with pore diameter specified as $\mathbf{1}$ oo $\mu \mathrm{m}$.

To test the hypothesis of an excess water film, we carried out regelation experiments over the rough but porous surface of commercial sintered glass (Fig. 2). Unfortunately the roughness of such a surface cannot be measured by the optical diffraction technique and so we roughly estimate the expected regelation velocities from the equation: $\nu=\alpha \lambda \tau / A^{2}$ assuming that $\lambda=4 A$ and $A=2 p$, where $p$ is the mean pore diameter specified by the manufacturer of the sintered glass. Section B of Table I shows that theoretical and measured velocities of movement are in much better agreement for the sintered glass surfaces than for the ground glass surfaces. We suggest that this is because the excess water produced by frictional melting can drain away from the interface between ice and sintered glass.

It has often been proposed that water at the bed may control the sliding of temperate glaciers. Theories and field observations are reviewed by Paterson (1969). Lliboutry (1968), emphasizes the importance of water under pressure in subglacial cavities. Weertman (1964, 1972) discusses the effects of a sheet of water at the bed upon the processes of regelation and draining, while Nye (1973[b]) points out some theoretical difficulties in reconciling these simultaneous processes. The present laboratory results emphasize the importance of water and the complexity of processes at a glacier bed. It seems that in order to understand the contribution of regelation to glacier sliding we must take account of the distribution of pores and drainage channels in both rock bed and ice (Nye and Frank, 1973) and consider the distribution and pressure of water in this hydraulic system. Further laboratory experiments on the regelation of ice over natural rock and artificial porous surfaces are planned. 


\section{Acknowledgements}

The authors wish to thank Professor J. F. Nye and Dr M. V. Berry, both of the University of Bristol, for their advice and help during this work.

\section{MS. received I7 Fuly 1974}

\section{REFERENGES}

Drake, L. D., and Shreve, R. L. 1973. Pressure melting and regelation of ice by round wires. Proceedings of the Royal Society of London, Ser. A, Vol. 332 , No. 1588, p. $51-83$.

Frank, F. C. 1967. Regelation: a supplementary note. Philosophical Magazine, Eighth Ser., Vol. 16, No. 144, p. $1267-74$.

Kamb, W. B. 1970. Sliding motion of glaciers: theory and observation. Reviews of Geophysics and Space Physics, Vol. 8, No. 4, p. $673^{-728}$.

Lliboutry, L. A. 1968. General theory of subglacial cavitation and sliding of temperate glaciers. Fournal of Glaciology, Vol. 7, No. 49, p. $21-58$.

Morris, E. M. Unpublished. The sliding of ice over rock and other substances. [Ph.D. thesis, University of Bristol, 1972.]

Nye, J. F. 1967. Theory of regelation. Philosophical Magazine, Eighth Ser., Vol. 16, No. 144, p. $1249-66$.

Nye, J. F. 1969. A calculation of the sliding of ice over a wavy surface, using a Newtonian viscous approximation. Proceedings of the Royal Society of London, Ser. A, Vol. 311 , No. 1506, p. $445-67$.

Nye, J. F. I970. Glacier sliding without cavitation in a linear viscous approximation. Proceedings of the Royal Society of London, Ser. A, Vol. 315 , No. 1522, p. $3^{81-403 .}$

Nye, J. F. 1973[a]. The motion of ice past obstacles. (In Whalley, E., and others, ed. Physics and chemistry of ice: papers presented at the Symposium on the Physics and Chemistry of Ice, held in Ottawa, Canada, 14-18 August 1972. Edited by E. Whalley, S. F. Fones, L. W. Gold. Ottawa, Royal Society of Canada, p. 387-94.)

Nye, J. F. 1973[b]. Water at the bed of a glacier. Union Géodésique et Géophysique Internationale. Association Internationale d'Hydrologie Scientifique. Commission de Neiges et Glaces. Symposium on the Hydrology of Glaciers, Cambridge, 7-13 September 1969, organized by the Glaciological Society, p. 189-94.

Nye, J. F., and Frank, F. C. 1973. Hydrology of the intergranular veins in a temperate glacier. Union Géodésique et Géophysique Internationale. Association Internationale d'Hydrologie Scientifique. Commission de Neiges et Glaces. Symposium on the Hydrology of Glaciers, Cambridge, 7-13 September 1969, organized by the Glaciological Society, p. $157-61$.

Ornstein, L. S. 1906. Over de beweging van een metaaldraad door een stuk ijs. Koninklijke Akademie van Wetenschappen te Amsterdam. Verslag van de Gewone Vergaderingen der Wis-en Natuurkundige Afdeeling, Deel I4, 2, p. 629-35.

Paterson, W. S. B. I969. The physics of glaciers. Oxford, etc., Pergamon Press. (The Commonwealth and International Library. Geophysics Division.)

Weertman, J. 1957. On the sliding of glaciers. Fournal of Glaciology, Vol. 3, No. 21, p. 33-38.

Weertman, J. 1964. The theory of glacier sliding. Journal of Glaciology, Vol. 5, No. 39, p. $287-303$.

Weertman, J. 1972. General theory of water flow at the base of a glacier or ice sheet. Reviews of Geophysics and Space Physics, Vol. 10, No. 1, p. 287-333. 